\title{
Bioavailability of organic matter in the sediments of the Porcupine Abyssal Plain, northeastern Atlantic
}

\author{
R. Danovaro ${ }^{1,2, *}$, A. Dell'Anno ${ }^{1,2}$, M. Fabiano ${ }^{3}$ \\ ${ }^{1}$ Department of Zoology, University of Bari, Via Orabona 4, 70125 Bari, Italy \\ ${ }^{2}$ Institute of Marine Science, University of Ancona, Via Brecce Bianche, 60131 Ancona, Italy \\ ${ }^{3}$ Department for the Study of the Territory and its Resources, University of Genoa, Corso Europa 26, 16132 Genova, Italy
}

\begin{abstract}
We investigated spatial and temporal changes in quantity, quality and bioavailability of organic matter in abyssal sediments of the northeastern Atlantic. Sediment samples were collected in the Porcupine Abyssal Plain (PAP, $4800 \mathrm{~m}$ depth) during 6 oceanographic cruises from September 1996 to October 1998 down to a depth of $15 \mathrm{~cm}$. Sedimentary proteins, carbohydrates and lipids, and their enzymatically hydrolysable fractions showed significant temporal changes, but different biochemical classes displayed different temporal patterns. Total proteins, carbohydrates and lipids displayed high concentrations, whereas the potentially hydrolysable fractions accounted for only about $10 \%$ of their total pools. From September 1996 to October 1998, bioavailable organic carbon concentration in the sediments decreased about $10 \mathrm{gC} \mathrm{m}^{-2}$ indicating that this benthic system was not steady state. Hydrolysed proteins and carbohydrates were characterised by different vertical patterns. Carbohydrates increased their relative significance with depth in the sediment indicating a shift of organic matter bioavailability with important trophodynamic implications for subsurface consumers. Vertical profiles of 'reactive' and refractory organic carbon in PAP sediments indicate that organic matter bioavailability in deeper sediment layers is higher than expected from previous theoretical models.
\end{abstract}

KEY WORDS: Deep-sea sediments · Organic matter · Bioavailability

\section{INTRODUCTION}

Quantity and quality of deep-sea sediment organic matter (OM) are largely dependent upon several factors including origin, composition and biochemical transformations that occur on organic particles during their descent to the ocean floor (Billett et al. 1983, Lochte \& Turley 1988, Wakeham et al. 1997, Danovaro et al. 1999).

Defining organic matter quality means discriminating between labile and refractory organic compounds (Mayer 1989). Its composition, indeed, is important both in a biogeochemical perspective (as OM degradation rates might affect its burial in the sediments; Hartnett et al. 1998) and from a trophodynamic point of

*E-mail: danovaro@popcsi.unian.it view (as OM availability influences feeding strategies and the distribution of benthic organisms; Jumars \& Penry 1989, Graf 1992). The labile portion of OM mainly consists of simple and/or combined compounds (i.e. biopolymers), and includes carbohydrates, lipids, proteins and nucleic acids that are rapidly mineralised whilst the refractory matter, composed by complex substances like humic and fulvic acids, is slowly broken down (Henrichs 1992). Some labile compounds might become recalcitrant to degradation as a result of the complex interactions occurring with the sedimentary matrix and/or refractory organic macromolecules (Keil et al. 1994).

The determination of the labile fraction of sedimentary organic matter is a difficult task, and a universally accepted method does not exist yet (Dell'Anno et al. 2000). Some authors have tentatively estimated the labile fraction of sedimentary organic matter through 
the determination of the main biochemical classes of organic compounds (i.e. carbohydrates, proteins and lipids), which are assumed to be easier to digest and assimilate (Fichez 1991, Danovaro et al. 1993, Fabiano et al. 1995, Tselepides et al. 2000). However, such an approach could not be efficient as total carbohydrate determination does not discriminate between highly refractory structural components and easily degradable compounds (and/or monomers; Buscail et al. 1995). An alternative approach, based on an enzymatic hydrolysis of sediment samples carried out in the laboratory, has been previously proposed for mimicking OM degradation steps in deposit feeding (George 1964, Mayer et al. 1995, Dauwe et al. 1999). OM susceptible of enzymatic hydrolysis has been recently proposed to represent the potentially bioavailable OM for benthic heterotrophic metabolism (Dell'Anno et al. 2000).

In this study, we adopted this concept of bioavailable organic matter and applied the method based on enzymatic digestion experiments on deep-sea sediments in order to: (1) estimate the potentially bioavailable organic fraction of different biochemical components of sedimentary organic matter; (2) investigate temporal changes in the quality and bioavailability of deep-sea $\mathrm{OM}$ in relation to OM inputs from the water column; and (3) investigate changes in OM bioavailability with depth in the sediment core to gather information in the 'optimal foraging theory' perspective (Taghon \& Jumars 1984).

\section{MATERIALS AND METHODS}

Study area and sampling. Sediment sampling was carried out in the Porcupine Abyssal Plain (PAP, northeastern Atlantic at about $4850 \mathrm{~m}$ depth; $48^{\circ} 50.2^{\prime} \mathrm{N}, 16^{\circ}$ $29.9^{\prime} \mathrm{W}$ ) in September 1996, March, July and October 1997, and, March and October 1998. This area is characterised by high sedimentation rates (average settling rate at $3100 \mathrm{~m}$ depth $110 \pm 30 \mathrm{~m} \mathrm{~d}^{-1}$; Newton et al. 1994) and a strong variability in OM fluxes (Rice et al. 1994). Undisturbed sediment samples were collected using a multicorer (Mod. Maxicorer, i.d., $9.0 \mathrm{~cm}$, depth penetration $>20 \mathrm{~cm}$ ). During each cruise, 4 to 10 cores were taken from 4 to 7 different deployments. Upon recovery all cores were vertically divided into 5 layers: 0 to 5,10 to 20,30 to 40,50 to 60 and 100 to $150 \mathrm{~mm}$ and deep frozen at $-20^{\circ} \mathrm{C}$ until analysis. All analyses were performed within 4 to $5 \mathrm{wk}$ after sediment collection.

Determination of the potentially available proteins. Details on protein and carbohydrate enzymatic hydrolysis of deep-sea sediment samples are reported in Dell'Anno et al. (2000). Frozen sediment samples were homogenised in $0.1 \mathrm{M}$ Tris, $0.1 \mathrm{M}$ EDTA ( $\mathrm{pH}$ 7.5) containing $1 \mathrm{mM}$ DTT (dithiothreitol; sediment:buffer ratio of $2.5 \mathrm{w} / \mathrm{v}$ ) and sonicated 3 times for $1 \mathrm{~min}$ (with intervals of $30 \mathrm{~s}$ ) before enzymes addition. Replicate samples of the slurry $(n=3)$ from each sediment layer (i.e. treated samples) were added to $100 \mu \mathrm{l}$ of proteinase-K $\left(1 \mathrm{mg} \mathrm{ml}^{-1}\right)$ and $100 \mu \mathrm{l}$ of protease $\left(600 \mu \mathrm{g} \mathrm{ml}^{-1}\right)$; another set of replicates was added to an equal volume of Tris-EDTA solution without enzymes (i.e. control samples). All samples were incubated for $2 \mathrm{~h}$ at $37^{\circ} \mathrm{C}$ under gentle agitation and subsequently filtered onto GF/F filters and rinsed 2 times with $5 \mathrm{ml}$ of cold $0.1 \mathrm{M}$ Tris$\mathrm{HCl}(\mathrm{pH} 7.5)$, in order to remove the digested protein fraction and the enzymes from the sediments. Sediment sub-samples muffled at $550^{\circ} \mathrm{C}$ for $4 \mathrm{~h}$ and processed as describe above were utilised as blanks.

Protein analyses from these samples and from intact sediments were carried out according to Hartree (1972), modified by Rice (1982) to compensate for phenol interference. Protein concentrations were calculated from calibration curves of serum albumin (ranging from 2.5 to $50 \mu \mathrm{g} \mathrm{ml}^{-1}$ ). Differences between protein concentration of control and treated samples were assumed to represent the concentration of proteins actually hydrolysed by proteases (hydrolysed proteins, HPRT). Total protein concentrations from intact sediments (TPRT) and HPRT concentrations were normalised to sediment dry weight.

Determination of the potentially available carbohydrates. For enzymatic digestion of sedimentary carbohydrate pools, frozen sediment samples were homogenised with $0.1 \mathrm{M} \mathrm{Na}$-Phosphate, 0.1 M EDTA (pH 6.9; sediment:buffer ratio of $2.5 \mathrm{w} / \mathrm{v}$ ) and sonicated 3 times for $1 \mathrm{~min}$ (with intervals of $30 \mathrm{~s}$ ). Replicate samples of the slurry ( $\mathrm{n}=3$, treated samples) were added to $100 \mu \mathrm{l}$ of $\alpha$-amylase, $50 \mu \mathrm{l}$ of $\beta$-glucosidase, $100 \mu \mathrm{l}$ of Proteinase $\mathrm{K}$ and $100 \mu \mathrm{l}$ of lipase (stock solution of all enzymes was $1 \mathrm{mg} \mathrm{ml}^{-1}$ ). Another set of replicates treated adding $0.1 \mathrm{M} \mathrm{Na}$-Phosphate instead of enzyme solutions was utilised as control. Samples were incubated for $2 \mathrm{~h}$ at room temperature under gentle agitation. As for protein hydrolysis, sediment sub-samples, muffled at $550^{\circ} \mathrm{C}$ for $4 \mathrm{~h}$ and processed as describe above were utilised as blanks. After incubation, all samples were centrifuged at $2000 \times g$ for $10 \mathrm{~min}$ and an aliquot of the supernatant was utilised to determine carbohydrates released from the sediments. Soluble carbohydrates were determined from the supernatant of the control sample. Carbohydrates from all supernatants and from intact sediments were analysed spectrophotometrically according to Dubois et al. (1956) and Gerchakov \& Hatcher (1972). Carbohydrate concentrations were calculated from calibration curves of D-glucose (from 10 to $200 \mu \mathrm{g} \mathrm{ml}^{-1}$ ). The actual fraction of hydrolysed carbohydrates (HCHO) was obtained by the difference between the carbohydrate concentrations determined in the supernatant of samples con- 
taining enzymes and the soluble fraction of the control. Total carbohydrate concentrations from intact sediments (TCHO) and $\mathrm{HCHO}$ concentrations were normalised to sediment dry weight.

Determination of lipids. The procedure utilised for protein digestion was also carried out to analyse the sedimentary lipid fraction hydrolysable by a lipase treatment (Triacylglycerol lipase, EC 3.1.1.3 SigmaAldrich). However, enzymatically hydrolysed lipid concentrations were very low $\left(<10 \mu \mathrm{g} \mathrm{g}^{-1}\right.$ in the $5 \mathrm{~mm}$ layer of sediments collected in September 1996) and undetectable below $5 \mathrm{~mm}$ depth and in the other sampling periods. Since a certain fraction of lipids is hydrophobic, these results could be influenced by the inefficacy of the rinsing step in removing enzymatically hydrolysed lipids. The difficulties we found in the enzymatic attack are consistent with results by Santos et al. (1994) who reported large amounts of lipids associated to the more recalcitrant fraction of sedimentary OM in PAP sediments. Our results are consistent with those reported by Galeron et al. (in press) who found a very low content of fatty acids (400 to $6000 \mathrm{ng} \mathrm{g}^{-1}$ ) analysed by gas-chromatography/mass spectrometry.

Total lipids were extracted from sediment samples by direct elution with chloroform and methanol (1:2 v/v) following the procedure of Bligh \& Dyer (1959) and analysed according to Marsh \& Weinstein (1966). All analyses were carried out on 3 to 4 replicates per sediment horizon. The same sediments previously treated at $550^{\circ} \mathrm{C}$ for $4 \mathrm{~h}$ were utilised as blanks. Lipid concentrations were calculated from calibration curves of tripalmitine (from 5 to $100 \mu \mathrm{g} \mathrm{ml}^{-1}$ ) and normalised to sediment dry weight.

Biopolymeric and bioavailable organic carbon. Biopolymeric organic carbon (BPC; sensu Fabiano et al. 1995) was defined as the sum of the carbon equivalents of total carbohydrates, proteins and lipids (utilising conversion factors of $0.4,0.49$ and 0.75 , respectively). Bioavailable organic carbon (BAOC) was defined as the sum of the carbon equivalents of hydrolysable carbohydrates and proteins, assuming the negligible contribution of the hydrolysable lipids.

Data analysis. A Spearman rank correlation analysis was performed to test for possible relationships among the investigated variables. Analyses of variance (ANOVA) were carried out to test for temporal and spatial differences in the investigated variables.

\section{RESULTS}

\section{Total proteins, carbohydrates and lipids}

Temporal changes in protein, carbohydrate and lipid concentrations in the top $5 \mathrm{~mm}$ of the sediment are re-

ported in Fig. 1. Protein, carbohydrate and lipid concentrations were characterised by significant temporal changes ( $p<0.01$ for the 3 variables) and generally displayed different temporal patterns. Total protein concentrations in the top $5 \mathrm{~mm}$ of the sediment were highest in September $1996\left(1422.3 \pm 23.1 \mu^{-1}\right)$ and lowest in July $1997\left(614.3 \pm 76.7 \mu \mathrm{g} \mathrm{g}^{-1}\right)$, whereas total carbohydrates doubled from July 1997 to March 1998 (1194.2 \pm 171.6 and $2210.1 \pm 39.5 \mu \mathrm{g} \mathrm{g}^{-1}$, respectively) Total lipids reached highest values in October 1998 $\left(775.2 \pm 24.0 \mathrm{\mu g} \mathrm{g}^{-1}\right)$ and lowest in March 1997 (140.0 \pm $19.5 \mathrm{\mu g} \mathrm{g}^{-1}$ ). We estimated that each multicorer deployment could occur in a range of about 1 mile, so that the low coefficient of variation for all variables (on average ca $10 \%$; here expressed as standard deviation/ mean $\times 100$ ) refers to this spatial variability.

On average for the 6 sampling periods, total carbohydrate, protein and lipid carbon accounted in the top $5 \mathrm{~mm}$ of the sediment for $15 \pm 2,12 \pm 2$ and $6 \pm 2 \%$, respectively, of the total organic carbon pool (TOC data summarised from Mackenzie et al. 1999).

a Total proteins

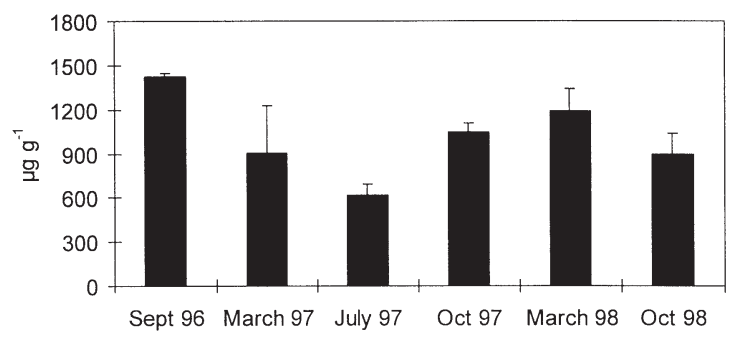

b Total carbohydrates

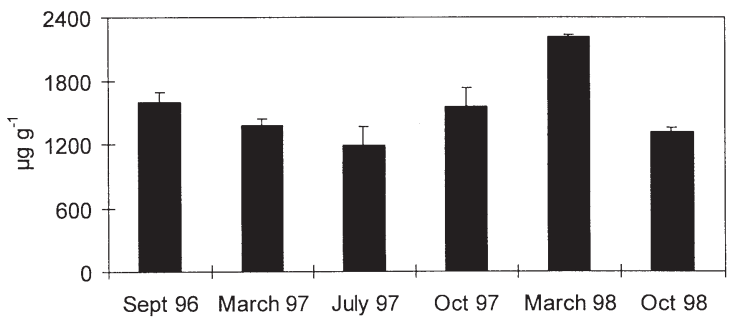

C Total lipids

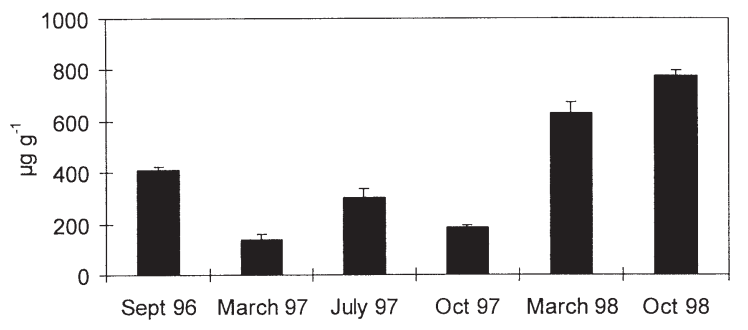

Fig. 1. Temporal changes in total protein (a), carbohydrate (b) and lipid (c) concentrations in the top 0 to $5 \mathrm{~mm}$ of sediment. Standard errors are reported 

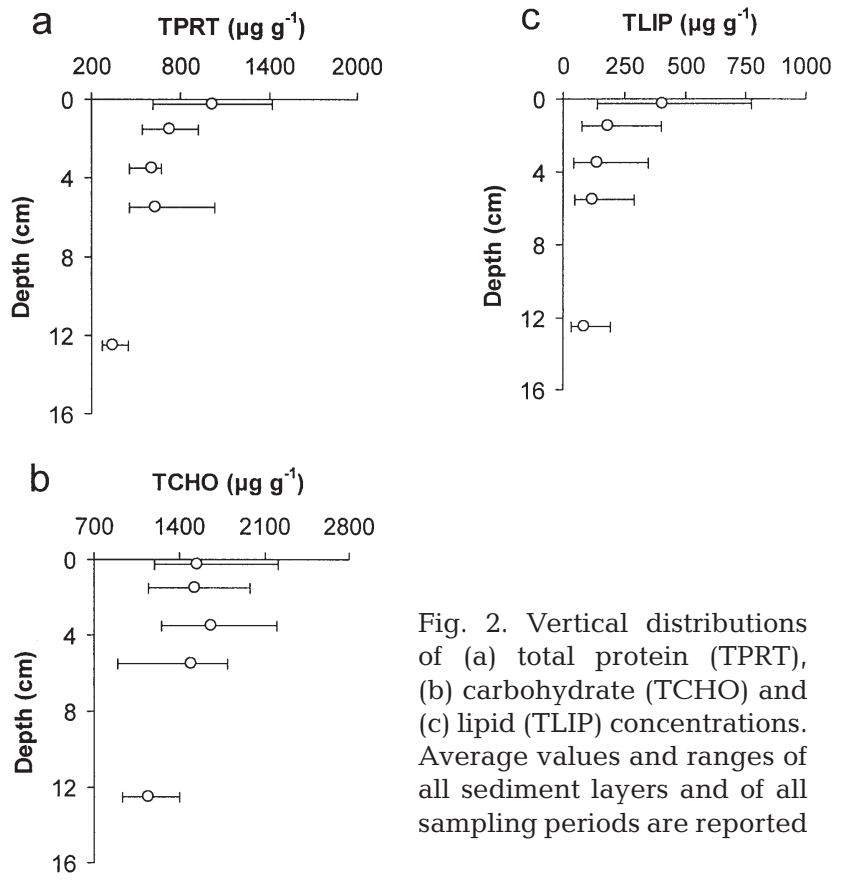

Fig. 2. Vertical distributions of (a) total protein (TPRT), (b) carbohydrate (TCHO) and (c) lipid (TLIP) concentrations. Average values and ranges of all sediment layers and of all sampling periods are reported

Vertical distributions of protein, carbohydrate and lipid concentrations in the sediment core are illustrated in Fig. 2. The 3 variables were characterised by a significant decrease with increasing depth in the sediment $(\mathrm{p}<0.01$ for proteins and lipids, and $\mathrm{p}<0.05$ for carbohydrates). However, protein and lipid concentrations sharply decreased from the top 0 to $5 \mathrm{~mm}$ of sediment to the deepest sediment layers (on average for the entire data set, 3- and 5-fold, respectively), whilst

\section{a Hydrolysed proteins}

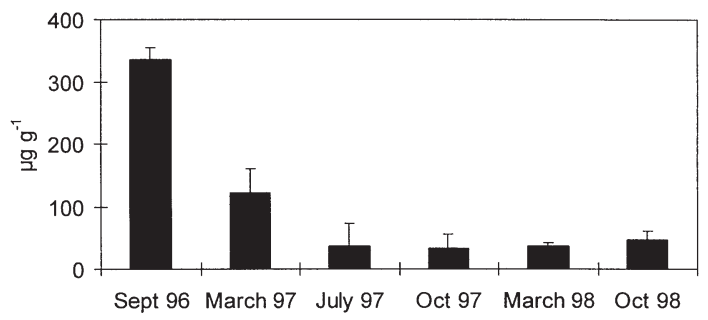

\section{b Hydrolysed carbohydrates}

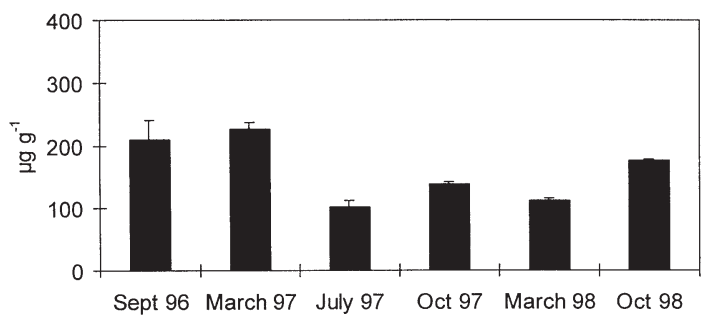

Fig. 3. Temporal changes in hydrolysed protein (a) and carbohydrate (b) concentrations in the top 0 to $5 \mathrm{~mm}$ of sediment. Standard errors are reported carbohydrate concentrations, more conservative, decreased by about $25 \%$ from the 0 to 5 to the 100 to $150 \mathrm{~mm}$ section of the sediment core.

\section{Hydrolysed proteins and carbohydrates}

Hydrolysed protein and carbohydrate concentrations were characterised by significant temporal changes ( $p<0.01$; Fig. 3). Highest HPRT concentrations were observed in September 1996 (335.3 $\pm 20.2 \mu \mathrm{g} \mathrm{g}^{-1}$ ) which then decreased by about $90 \%$ in October 1997; HCHO reached highest values in March 1997 (227.1 \pm

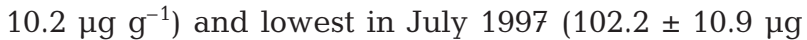
$\mathrm{g}^{-1}$ ). In the upper sediment layer (0 to $5 \mathrm{~mm}$ ), both HPRT and HCHO concentrations accounted on average for $10 \%$ of their total pools.

Significant differences in HPRT and HCHO concentrations were observed among sediment layers ( $\mathrm{p}<$ 0.05; Fig. 4). HPRT concentrations decreased 10-fold from the top $5 \mathrm{~mm}$ of sediment (on average for all sampling periods, $101.7 \pm 44.5 \mathrm{\mu g} \mathrm{g}^{-1}$ ) to the deepest sediment layers (i.e., 100 to $150 \mathrm{~mm}, 10.1 \pm 3.5 \mu \mathrm{g} \mathrm{g}^{-1}$ ), whilst HCHO concentrations decreased by only about $30 \%$.

\section{Biopolymeric and bioavailable organic carbon}

Temporal changes in biopolymeric and bioavailable organic carbon concentrations were different (Fig. 5). $\mathrm{BPC}$ concentrations in the 0 to $5 \mathrm{~mm}$ of sediment were relatively high (on average $1418.4 \pm 122.6 \mu \mathrm{g} \mathrm{g}^{-1}$ ) varying from 1003.9 to $1938.6 \mu \mathrm{g} \mathrm{g}^{-1}$ in July 1997 and March 1998, respectively. BAOC concentrations decreased by about 4-fold from September 1996 to July 1997 and accounted on average for all sampling periods for less than $10 \%$ of BPC pools, whereas BPC accounted for $33 \%$ of TOC concentrations. BPC and

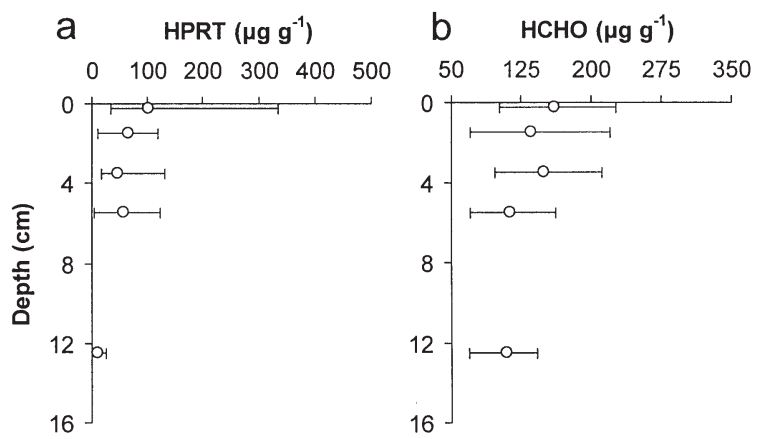

Fig. 4. Vertical distributions of (a) hydrolysed protein (HPRT) and (b) carbohydrate (HCHO) concentrations. Average values and ranges of all sediment layers and of all sampling periods are reported 


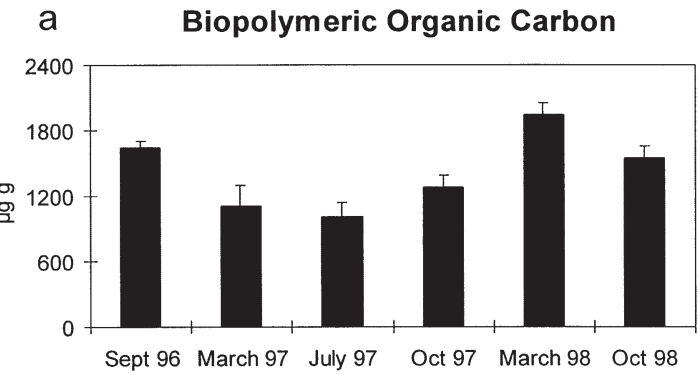

b Bioavailable Organic Carbon

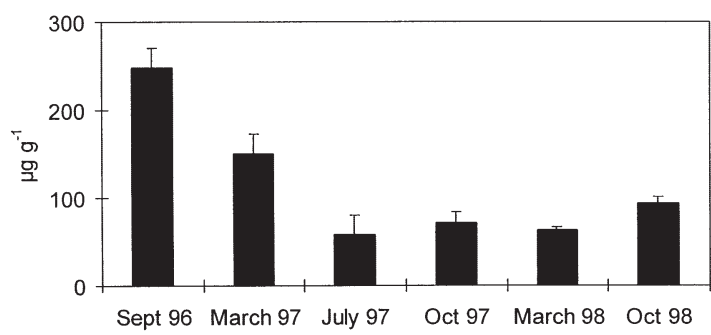

Fig. 5. Temporal changes in (a) biopolymeric and (b) bioavailable organic carbon concentrations in the top 0 to $5 \mathrm{~mm}$ of sediment. Standard errors are reported

BAOC decreased significantly from the top $5 \mathrm{~mm}$ to the deepest sediment layers $(\mathrm{p}<0.01$ and $\mathrm{p}<0.05$ for BPC and BAOC, respectively; Fig. 6). Carbohydrates were the dominant component of BPC accounting in the top $5 \mathrm{~mm}$ of sediment for $45 \%$, followed by proteins ( $35 \%$ ) and lipids $(20 \%)$. Carbohydrate contribution to BPC pool increased by up to about $70 \%$ in the deepest sediment layer, where hydrolysed carbohydrates accounted for $>90 \%$ of the BAOC pool.

\section{DISCUSSION}

\section{Bioavailable fraction of OM in PAP sediments}

The biochemical composition of the sedimentary organic matter could be assumed as an estimate of the material potentially available to benthic consumers (Fichez 1991, Danovaro et al. 1993, Fabiano et al. 1995, Tselepides et al. 2000). Sedimentary protein, carbohydrate and lipid concentrations reported in this study were high when compared to deep-sea values collected worldwide (Sibuet 1984, Pfannkuche \& Thiel 1987, Danovaro et al. 1993, Boetius et al. 1996, Tselepides et al. 2000), indicating that the Porcupine Abyssal Plain is characterised by trophic conditions typical of shelf environments. This is not surprising since the PAP area is characterised by a large phytodetritus deposition to the sea floor (Rice et al. 1986, 1994, Thiel et al. 1988/1989). Organic compounds resistant to bio-

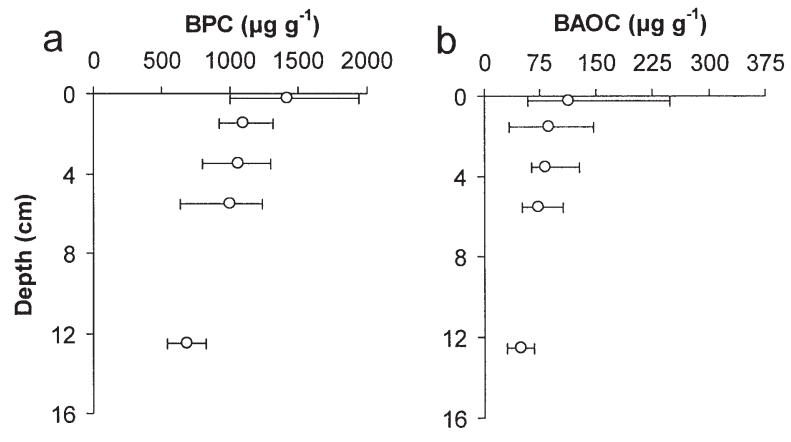

Fig. 6. Vertical distributions of (a) biopolymeric (BPC) and (b) bioavailable organic carbon (BAOC) concentrations. Average values and ranges of all sediment layers and of all sampling periods are reported

logical degradation are easily accumulated in the sediments (Rowe et al. 1990). Proteins and carbohydrates enzymatically hydrolysed (assumed to be generally available to benthic deposit feeders; Mayer et al. 1995, Dell'Anno et al. 2000) in PAP sediments accounted only for a minor fraction (about $10 \%$ ) of their respective total pools indicating that TPRT and TCHO do not represent the actual available fraction of OM (i.e. digestible by heterotrophs).

Previous studies reported that the present approach for estimating bioavailable OM from frozen sediments might overestimate the bioavailable fraction (Mayer et al. 1995, Dauwe et al. 1999). Dell'Anno et al. (2000) stressed also that since enzyme activities are maximised for temperature and $\mathrm{pH}$, all values should be considered as estimates of the potential OM bioavailability.

In PAP sediments, BAOC concentrations were significantly related with BPC content (Fig. 7; $\mathrm{n}=30, \mathrm{r}=$ 0.417, $\mathrm{p}<0.05$ ), even though they accounted for less than $10 \%$ of BPC pools. For coastal sediments, George (1964) reported that about $14 \%$ of the total organic carbon is hydrolysed by enzymes. As in the top $5 \mathrm{~mm}$ of the sediment, BPC concentrations accounted for $33 \%$ of the total organic carbon content (on average $4.6 \pm$ $0.2 \mathrm{mg} \mathrm{g}^{-1}$ for the entire study period); these results indicate that in deep-sea sediments, a minor fraction of total organic carbon pool is actually available to ben-

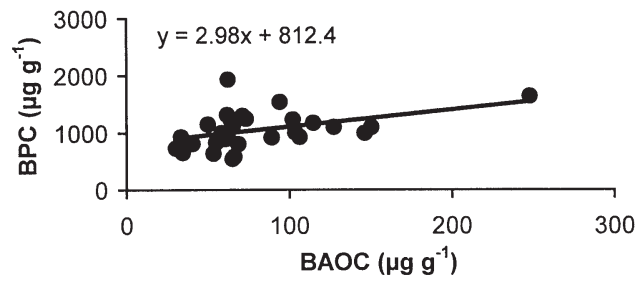

Fig. 7. Relationship between bioavailable (BAOC) and biopolymeric (BPC) organic carbon concentrations in the PAP sediments at each depth and in all sampling periods 
thic consumers. This finding strongly supports the conclusion drawn by Fabiano et al. (1995), that total sediment organic carbon does not represent an estimate of the actual food availability to the benthos.

\section{Temporal changes in the quality and bioavailability of $\mathbf{O M}$}

All the investigated variables showed significant temporal changes, whilst total organic carbon concentrations were highly conservative (Mackenzie et al. 1999). These results are in agreement with data reported from long-term temporal series carried out in coastal sediments (Fabiano et al. 1995), and indicate that temporal changes and interannual variability of organic content in deep-sea sediments are evident only when the OM biochemical composition is investigated.

Total protein, carbohydrate and lipid pools displayed different temporal patterns. Synoptic studies reported that seasonal changes in quantity and composition of particle fluxes were very similar for all biochemical classes of organic compounds (Table 1 ; flux data from Fabiano et al. in press), indicating that in the PAP area, changes observed in sediment organic matter are uncoupled with their respective inputs from the water column. Therefore, it is likely that different rates of accumulation and/or degradation characterise the different classes of organic compounds when particle fluxes reach the sediment surface. This is not surprising since proteins are preferentially utilised by benthic consumers (Tenore 1988, Danovaro et al. 1999) and represent the limiting compound in most deep-sea environments (Deming \& Baross 1993). In this regard, hydrolysed proteins are by far the most temporally variable class of organic compounds.

Deep-sea environments are generally assumed to be in a steady state. However, in situ measurements of $\mathrm{CO}_{2}$ and dissolved organic carbon proved the presence of a negative balance of $\mathrm{C}$ inputs vs outputs from the PAP sediments (Rabouille et al. in press). From September 1996 to October 1998, BAOC concentrations in the top $15 \mathrm{~cm}$ of the sediment decreased by about $9 \mathrm{gC}$ $\mathrm{m}^{-2}$. In the same period, we observed that protein and carbohydrate carbon fluxes were cumulatively equivalent to about $1 \mathrm{gC} \mathrm{m}^{-2}$ (from synoptic data reported by Fabiano et al. in press). Therefore, labile organic compounds could represent the reservoir directly utilised by deep-sea benthic organisms during periods of limited organic matter supply. This was the case in our study in 1997, when no appreciable amounts of phytodetritus were detected by bathysnap observations (Bett et al. in press).

\section{Vertical distribution of the bioavailable OM: trophic implications}

The analysis of the vertical distribution of the different biochemical classes of organic compounds highlighted clear differences between surface and deep sediment layers. In the top $5 \mathrm{~mm}$ of the sediment, HPRT accounted for $10 \%$ of TPRT whereas their contribution decreased to $3 \%$ in the 100 to $150 \mathrm{~mm}$ sediment layer. By contrast, $\mathrm{HCHO}$ accounted for about $10 \%$ of TCHO throughout the sediment core. These data indicate that different organic compounds might play different roles in different sediment layers. In the surface sediments, hydrolysable proteins and carbohydrates represent a roughly equivalent source of bioavailable carbon whereas in deeper sediment layers carbohydrates represent the almost entire food source. These results might have profound implications for benthic trophodynamics. According to the optimal foraging theory, limivorous organisms (i.e., subsurface deposit feeders, which usually feed beneath the sediment mixing depth, ca 4 to $5 \mathrm{~cm}$ in the PAP sediments; Patching et al. in press) can compensate the low amount of available OM in deeper sediment layers,

Table 1. Temporal patterns of protein and carbohydrate fluxes at $3000 \mathrm{~m}$ depth (integrated to 1 mo before sediment sampling) and the concentration of proteins and carbohydrates in the top 0 to $5 \mathrm{~mm}$ of sediment in the Porcupine Abyssal Plain. SE = standard error; na = not available

\begin{tabular}{|c|c|c|c|c|c|c|c|c|}
\hline \multirow{3}{*}{ Sampling period } & \multicolumn{4}{|c|}{ Labile organic matter fluxes } & \multicolumn{4}{|c|}{ Sediment organic matter } \\
\hline & \multicolumn{2}{|c|}{ Carbohydrates } & \multicolumn{2}{|c|}{ Proteins } & \multicolumn{2}{|c|}{ Carbohydrates } & \multicolumn{2}{|c|}{ Proteins } \\
\hline & $\mathrm{mgC} \mathrm{m}^{-2} \mathrm{~d}^{-1}$ & SE & $\mathrm{mgC} \mathrm{m} \mathrm{m}^{-2} \mathrm{~d}^{-1}$ & SE & $\mathrm{mgC}^{-1}$ & SE & $\mathrm{mgC}^{-1}$ & SE \\
\hline Sep 1996 & 1.16 & na & 0.15 & na & 0.64 & 0.03 & 0.70 & 0.01 \\
\hline Mar 1997 & 0.27 & 0.08 & 0.04 & 0.03 & 0.55 & 0.02 & 0.44 & 0.16 \\
\hline Jul 1997 & 1.40 & 0.45 & 0.44 & 0.28 & 0.48 & 0.07 & 0.30 & 0.04 \\
\hline Oct 1997 & 0.47 & 0.04 & 0.39 & 0.10 & 0.62 & 0.07 & 0.51 & 0.03 \\
\hline Mar 1998 & 0.33 & 0.07 & 0.60 & 0.29 & 0.88 & 0.01 & 0.58 & 0.07 \\
\hline Oct 1998 & 1.60 & 0.44 & 1.47 & 0.52 & 0.53 & 0.01 & 0.44 & 0.07 \\
\hline
\end{tabular}



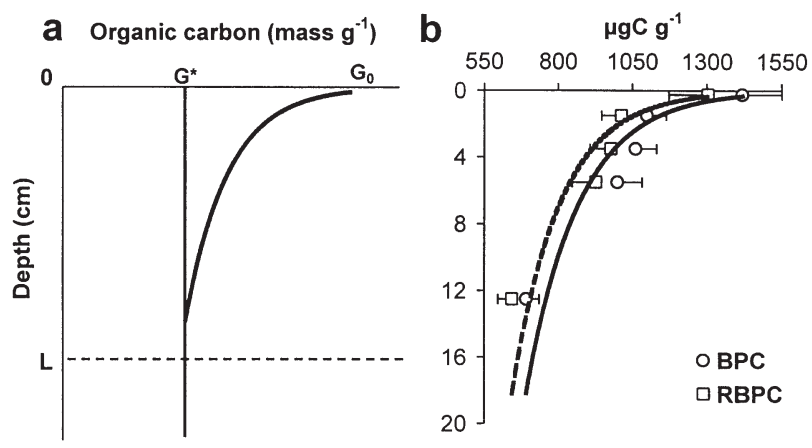

Fig. 8. Comparison between: (a) the Rice \& Rhoads (1989) model $\left(G^{*}\right.$ is a non-zero asymptotic concentration of organic carbon profiles and $G_{0}$ is its surface maximum concentration; $L$ is the mixing depth in $\mathrm{cm}$ ); and (b) the model obtained in this study from the vertical distribution of biopolymeric carbon (BPC) and refractory BPC (i.e., RBPC, as the difference between BPC and BAOC concentrations). Average values (as $\mu \mathrm{gC}^{-1}$ ) of all sediment layers and all sampling periods are reported. Standard errors are indicated. Tendency curve equations for BPC (continuous line) and RBPC (broken line) are: $\mathrm{BPC}=-198.37 \ln ($ depth $)+1288\left(\mathrm{R}^{2}=0.952\right)$ and $\mathrm{RBPC}=$ $-180.12 \ln ($ depth $)+1185.4\left(R^{2}=0.949\right)$

with a diminished competition for available resources (Jumars et al. 1990). According to our results, subsurface consumers would be also subjected to a different diet regime characterised by a large predominance of carbohydrates and, possibly, different adaptive mechanisms to optimise the exploitation of this trophic source.

The vertical distribution of 'reactive' and refractory (i.e., less rapidly degraded) organic carbon pools (estimated as differences between BPC and BAOC content) in PAP sediments is illustrated in Fig. 8 and compared to the theoretical model proposed by Rice \& Rhoads (1989). They proposed that depth profile of OC in the bioturbated zone can be approximated by an exponential function $G(x)$ that decreases with depth $\mathrm{x}$ from a surface maximum concentration $G_{0}$ to a nonzero asymptotic concentration $G^{*}$. Conversely to that hypothesised by Rice \& Rhoads (1989), who assumed a constant $\left(G_{0}\right.$; Fig. 8) content of refractory organic carbon with depth in the sediment, our data indicate that the refractory organic carbon pool (and not only the bioavailable fraction) decreases exponentially with depth. Moreover, our results point out that the bioavailable organic carbon in the top $5 \mathrm{~mm}$ of the sediments represent a much smaller fraction than the one theoretically calculated from the difference between $G_{0}$ and $G^{*}$ (Rice \& Rhoads 1989). On the other hand, the bioavailable fraction in the deeper sediment layers, estimated with our approach, is higher than expected, assuming an exponential decrease with depth, as suggested by Rice \& Rhoads (1989). These results could be summarised as 'less bioavailable OM in the top and more bioavailable OM in the deep', though of a different quality. These conclusions are obviously the consequence of a different approach focussing on the main biochemical classes of organic compounds instead of on the bulk organic carbon, as in the model proposed by Rice \& Rhoads (1989), and further studies are needed to elucidate the mechanisms controlling organic matter bioavailbility in different marine sediments.

Acknowledgements. This work was carried out within the framework of the programme BENGAL: 'High resolution temporal and spatial study of the BENthic biology and Geochemistry of a northeastern Atlantic abyssal Locality' (MAS3CT950018).

\section{LITERATURE CITED}

Bett B, Malzone G, Narayanaswamy B, Wigham B (in press) Temporal variability in phytodetritus and megabenthic activity at the seabed in the deep northeast Atlantic. Prog Oceanogr

Billett DSM, Lampitt AS, Rice AL, Mantoura RFC (1983) Seasonal sedimentation of phytoplankton to the deep-sea benthos. Nature 302:520-522

Bligh EG, Dyer W (1959) A rapid method for total lipid extraction and purification. Can J Biochem Physiol 37:911-917

Boetius A, Scheibe S, Tselepides A, Thiel H (1996) Microbial biomass and activities in deep-sea sediments of the Eastern Mediterranean: trenches are benthic hotspots. Deep Sea Res 43:1439-1460

Buscail R, Pocklington R, Germain C (1995) Seasonal variability of the organic matter in a sedimentary coastal environment: sources, degradation and accumulation (continental shelf of the Gulf of Lions-northwestern Mediterranean Sea). Cont Shelf Res 15:843-869

Danovaro R, Dinet A, Duineveld G, Tselepides A (1999) Benthic response to particulate fluxes in different trophic environments: a comparison between the Gulf of LionsCatalan sea (W-Mediterranean) and the Cretan Sea (EMediterranean). Prog Oceanogr 44:287-312

Danovaro R, Fabiano M, Della Croce N (1993) Labile organic matter and microbial biomasses in deep-sea sediments (Eastern Mediterranean Sea). Deep Sea Res I 40:953-965

Dauwe B, Middelburg JJ, Van Rijswijk P, Sinke J, Herman PMJ, Heip CHR (1999) Enzymatically hydrolysable amino acids in North Sea sediments and their possible implication for sediment nutritional values. J Mar Res 57:109-134

Dell'Anno A, Fabiano M, Mei ML, Danovaro R (2000) Enzymatically hydrolysed protein and carbohydrate pools in deep-sea sediments: estimates of the potentially bioavailable fraction and methodological considerations. Mar Ecol Prog Ser 196:15-23

Deming JW, Baross JA (1993) The early diagenesis of organic matter: bacterial activity. In: Engel M, Macko S (eds) Organic geochemistry, 6 topics in geobiology. Plenum Press, New York, p 119-144

Dubois M, Gillesha K, Milton JK, Rebers PA, Smith F (1956) Colorimetric method for determination of sugars and related substances. Anal Chem 28:350-356

Fabiano M, Danovaro R, Fraschetti S (1995) A three-year time series of elemental and biochemical composition of organic matter in subtidal sandy sediments of the Ligurian 
Sea (northwestern Mediterranean). Cont Shelf Res 15: 1453-1469

Fabiano M, Pusceddu A, Dell'Anno A, Armeni M, Vanucci S, Lampitt R, Wolff GA, Danovaro R (in press) Fluxes of phytopigments and labile organic matter to the deep ocean in the NE Atlantic Ocean. Prog Oceanogr

Fichez R (1991) Composition and fate of organic matter in submarine cave sediments; implications for the biogeochemical cycle of organic carbon. Oceanol Acta 14: 369-377

Galeron J, Sibuet M, Venreusel A, Mackenzie K, Gooday AJ, Wolff G (in press) Are temporal patterns among meiofaunal and macrofaunal taxa (quantitative distribution) at an abyssal N-E Atlantic site influenced by sediment lipid chemistry? Prog Oceanogr

George JD (1964) Organic matter available to the polychaete Cirriformia tentaculata (Montagu) living in an intertidal mud flat. Limnol Oceanogr 9:453-455

Gerchakov SM, Hatcher PG (1972) Improved technique for analysis of carbohydrates in sediments. Limnol Oceanogr $17: 938-943$

Graf G (1992) Benthic-pelagic coupling: a benthic view. Oceanogr Mar Biol Ann Rev 30:149-190

Hartnett HE, Keil RG, Hedges JI, Devol AH (1998) Influence of oxygen exposure time on organic carbon preservation in continental margin sediments. Nature 391:572-574

Hartree EF (1972) Determination of proteins. a modification of the Lowry methods that given a linear photometric response. Anal Biochem 48:422-427

Henrichs SM (1992) Early diagenesis of organic matter in marine sediments: progress and perplexity. Mar Chem 39: 119-149

Keil RG, Montlucon DB, Prahl FG, Hedges JI (1994) Sorptive preservation of labile organic matter in marine sediments. Nature 370:549-552

Jumars PA, Penry DL (1989) Digestion theory applied to deposit feeding. In: Lopez G, Taghon G, Levinton J (eds) Ecology of marine deposit-feeders. Lecture notes on coastal and estuarine studies. Springer-Verlag, New York, p 114-128

Jumars PA, Mayer LM, Deming JW, Baross JA, Wheatcroft RA (1990) Deep-sea deposit-feeding strategies suggested by environmental and feeding constraints. In: Charnock $\mathrm{H}$, Edmond JM, McCave IN, Rice AL, Wilson TRS (eds) The deep sea bed: its physics, chemistry and biology. Philos Trans R Soc Lond A 331:85-101

Lochte K, Turley CM (1988) Bacteria and cyanobacteria associated with phytodetrituts in the deep-sea. Nature 333: 67-69

Mackenzie K, Kiriakoulakis K, Wolff GA (1999) Labile organic matter in PAP sediments. Composition, distribution and temporal variation of lipids and intact proteins. Final Report BENGAL, Southampton Oceanographic Centre, Southampton, p 87-98

Marsh JB, Weinstein WJ (1966) A simple charring method for determination of lipids. J Lip Res 7:574-576

Mayer LM (1989) The nature and determination of living sedimentary organic matter as food source for deposit-feeders. In: Lopez G, Taghon G, Levinton J (eds) Ecology of marine deposit-feeders. Lecture notes on coastal and estuarine studies. Springer-Verlag, New York, p 98-113

Mayer LM, Schick LL, Sawyer T, Plante CJ, Jumars PA, Self RL (1995) Bioavailable amino acids in sediments: a biomimetic, kinetics-based approach. Limnol Oceanogr 40:511-520

Editorial responsibility: Otto Kinne (Editor),

Oldendorf/Luhe, Germany
Newton PR, Lampitt RS, Jickells TD, King P, Boutle C (1994) Temporal and spatial variability of biogenic particle fluxes during the JGOFS NE Atlantic Process studies at $47^{\circ} \mathrm{N}$ $20^{\circ}$ W. Deep-Sea Res I 41:1617-1642

Patching J, Vanreusel A, Lamont A, Gage JD, Vincx M (in press) Downcore seasonal spatial variability in micro, meio and macrofauna at an abyssal NE Atlantic site. Prog Oceanogr

Pfannkuche O, Thiel H (1987) Meiobenthic stocks and benthic activity on the northeast Svalbard Shelf and in the Nansen Basin. Polar Biol 7:253-266

Rabouille C, Stahl H, Bassinot F, Tengberg A, Brunnegard J, Hall P, Kiriakoulakis K, Reyss JL, Dezileau L, Lampitt R (in press) Imbalance in the carbonate budget of surficial sediment in the North Atlantic Ocean: millennium time scale variation? Prog Oceanogr

Rice AL, Billett DSM, Fry J, Johns AWG, Lampitt RS, Mantoura RFC, Morris J (1986) Seasonal deposition of phytodetritus to the deep-sea floor. Proc R Soc Edinb Sect B 88:265-279

Rice AL, Thurston MH, Bett BJ (1994) The IOSDL DEEPSEAS programme: photographic evidence for the presence and absence of seasonal input of phytodetritus at contrasting abyssal sites in the north-eastern Atlantic Ocean. DeepSea Res I 41:1305-1320

Rice DL (1982) The detritus nitrogen problem: New observations and perspectives from organic geochemistry. Mar Ecol Prog Ser 9:153-162

Rice DL, Rhoads DC (1989) Early diagenesis of organic matter and the nutritional value of sediment. In: Lopez G, Taghon G, Levinton J (eds) Ecology of marine deposit-feeders. Lecture notes on coastal and estuarine studies. SpringerVerlag, New York, p 60-97

Rowe GT, Sibuet M, Deming J, Tietjen J, Khripounoff A (1990) Organic carbon turnover time in deep-sea benthos. Prog Oceanogr 24:141-160

Santos V, Billett DSM, Rice AL, Wolff GA (1994) Organic matter in deep-sea sediments from the Porcupine Abyssal Plain in the north-east Atlantic Ocean. I-Lipids. Deep-Sea Res I 41:787-819

Sibuet M (1984) Deposit-feeding invertebrates in the deepsea ecosystem. Selectivity in feeding and diet of holothurians. Oceanis 10:623-876

Taghon GL, Jumars PA (1984) Variable ingestion rate and its role in optimal foraging behavior of marine deposit feeders. Ecology 65:549-558

Tenore KR (1988) Nitrogen in benthic food chains. In: Blackburn TH, Sorensen J (eds) Nitrogen cycling in coastal marine environment. John Wiley and Sons Ltd, p 191-206

Thiel HO, Pfannkuche O, Schriever G, Lochte K, Gooday AJ, Hemlebel C, Mantoura RFC, Turley CM, Patching JW, Rieman F (1988/1989) Phytodetritus on the deep-sea floor in a central oceanic region of the Northeast Atlantic. Biol Oceanogr 6:203-239

Tselepides A, Polychronaki T, Marrale D, Akoumianaki I, Dell'Anno A, Pusceddu A, Danovaro R (2000) Organic matter composition of the continental shelf and bathyal sediments of the Cretan Sea (NE Mediterranean). Prog Oceanogr 46:311-344

Wakeham SG, Hedges JI, Lee C, Peterson ML, Hernes PJ (1997) Compositions and transport of lipid biomarkers through the water column and surficial sediments of the equatorial Pacific Ocean. Deep-Sea Res II 44:2131-2162

Submitted: October 24, 2000; Accepted: February 27, 2001

Proofs received from author(s): September 17, 2001 